Archaeological Journal

\title{
Examples of Mediæval Seals
}

\section{A. W.}

To cite this article: A. W. (1851) Examples of Mediæval Seals, Archaeological Journal, 8:1, 74-78, DOI: $10.1080 / 00665983.1851 .10850815$

To link to this article: http://dx.doi.org/10.1080/00665983.1851.10850815

$$
\text { 曲 Published online: } 10 \text { Jul } 2014 .
$$

Submit your article to this journal $\sqrt{3}$

LII Article views: 1

Q View related articles ¿ 
similar cases. If the designation of any head should, from its brevity, seem obscure, probably such obscurity will be dissipated on calling to mind, that no head is intended to comprise what is clearly comprehended under any other which is numbered in the same series. For a purpose of this kind, it is not unreasonable, and has been found most convenient, to assume all seals to be lay which do not show themselves to be otherwise; and therefore the term "lay seals" has been made to comprise all seals that do not appear to be ecclesiastical ; and in this sense these words must be understood in the last division of that class.

W. S. W.

\section{EXAMPLES OF MEDIÆVAL SEALS.}

IT has been proposed to bring together, from time to time, notices of the numerous impressions and matrices of seals communicated at the meetings of the Institute. Such collections towards the History of Seals, occasionally illustrated by woodcuts, will, it is hoped, be more acceptable to the readers of the Journal than the incidental mention of them in the Reports of the meetings. They will form a suitable sequel to the foregoing scheme for their classification, the want of which has long been felt by the collector.

1. Common seal of the Benedictine Priory of St. Mary of Hurley, Berks, founded in the reign of the Conqueror by Geoffrey de Magna-villa. The conventual church, of which a portion, the western door, with chevrony mouldings, still exists, is said to have been dedicated by 0smond, Bishop of Salisbury, A.D. 1086. The Priory was a cell to the Abbey of Westminster.

The impression, from which the accompanying illustration has been taken, is appended to a deed whereby Prior Alexander and the convent granted their manor in Harefield, Middlesex, to Richard Weltekart of Louth (de Luda), Thomas his son, and Florence the wife of the same Thomas, to hold to them and the heirs of Thomas, of the chief lords of the fee, by the accustomed services, for ever. It was found by Mr. William F. Vernon amongst the evidences pertaining to his estate at Harefield, and communicated, by his kind permission, to the Institute. The deed is without date, but it may be assigned to the reign of the first or second Edward. The principal device is the Annunciation; between the angel Gabriel and the Virgin there is a vase with a lily, placed upon the apex of a pointed arch, which forms a compartment in the lower part of the seal ; within this is a kneeling 
ILLUSTRATIONS OF MEDIEVAL SEALS.

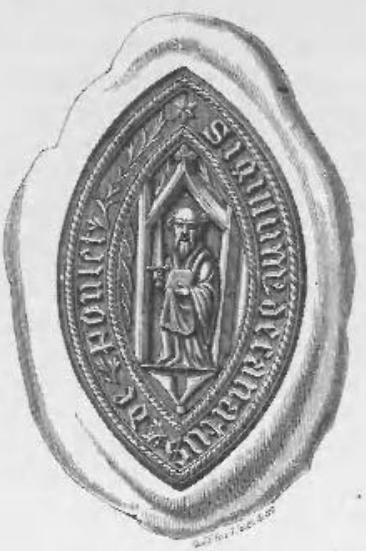

Seal of the Deanery of Pavlett Matrix found near $W$ inchester.

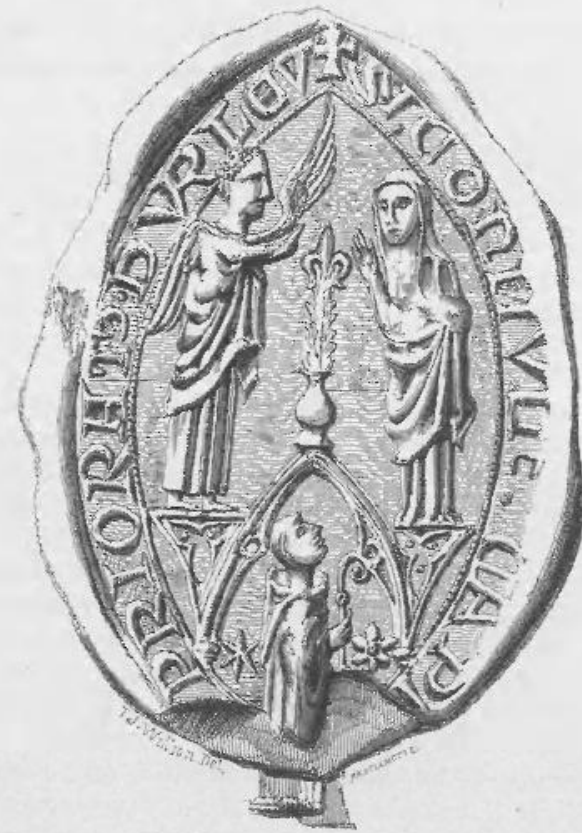

Seal of Hurley Priory, Berkshire.

From an Impression appended to a Deed in the possession of William F. Vernon, Esq. 
figure of the Prior, holding a crosier, his eyes upraised towards the Virgin. 0 n one side of this figure there is a mullet of six points, and on the other a flower of as many petals, the angemme of the French heralds. ${ }^{2}$ The legend is as follows- $\mathrm{s}^{\prime}$ CONMVNe . CA(PITVLI.) PRIORAT'. HVRLEY. It is unusual to see a Prior represented bearing a crosier. On the seal of Lewes Priory, St. Pancras is introduced, seemingly habited as a Cluniac Prior, and bearing a crosier. (Sussex Archæol. Coll. vol. ii. p. 20.)

Madox, in his "Formulare," p. 250, noticed two seals of Hurley priory appended to a grant by Prior Ralph de Arundel, promoted to Westminster, A.D. 1200 . This document was " in arch. S. Petri Westmon." One of the seals bore the head of the Virgin, around it- AVE MARIA GRA' PLENA, and was inscribed- ' SIGILL' RAD' DE ARVNDEL PRIORIS HERL'. On the reverse a counter-seal impressed with a lionTRIBV JVDA. The other seal was inscribed- SIGILLVM ECCL'IE SC'E DEI GENETRICIS DE HERLEIE. Madox does not describe its device.

In the Duchy of Lancaster Office there is a document, dated $34 \mathrm{Edw}$. I., to which is appended the seal of Alexander de Newport, Prior of Hurleyprobably the same Prior who is named in Mr. Vernon's deed.

2. Seal of the Rural Deanery of Poulet, or Pawlett, Somersetshire, in the Archdeaconry of Wells. According to the present ecclesiastical divisions, this Deanery comprises the rectories of Bawdrip, Cossington, Greinton, and Huntspill, with the vicarages of Pawlett and Woollavington, with Puriton.

These benefices are found, under the head "Decanatus de Poulet," in the Taxation of Pope Nicholas IV. circa 1291, (pp. 198, 202). Under another head, "Decanatus de Poulet, seu Jurisdictio Glaston'," are enumerated certain benefices, with the pensiones therein, appertaining to the Abbot of Glastonbury and the Sacrist.

The device of this official seal is a figure of St. Paul, holding a sword in his right hand, and a book in the left; the legend,-—* Giqiflum Jecanatus de goulet. It is unusual to find a star, in lieu of a cross, at the commencement of the legend, on an ecclesiastical seal.

There appears evidently to be some connexion between the name of the Apostle and that of the place. The patron saint, however, of the church of Pawlett, according to the obliging information of the vicar, the Rev. J. D. Crosse, is St. John the Baptist, not St. Paul. The Deanery probably derived its name from the principal place within its jurisdiction; but Pawlett has no necessary connexion with the office of Rural Dean. It is actually held by the Rector of Huntspill.

This matrix was found near Winchester, and presented, in Dec. 1849, to Dr. Mantell, by whom it was communicated to the Society. It is of yellow mixed-metal ; there is a ridge at the back, pierced in the middle for suspension. Its date appears to be the earlier part of the fifteenth century.

Dr. Pegge stated, in his remarks on the existence of so many matrices of conventual seals, that "several rural deans' seals are extant." $z$ Mr. Dansey has described those which had fallen under his notice in his chapter on the "Authentic Seal" of the Dean rural, which, in Bishop Kennett's

${ }^{1}$ On the seal of Pershore Abbey, apparently of the same period as that of Hurley, the crescent appears on one side of the Virgin, with the star on the other; and in other parts are introduced a quatrefoil, a flower of six petals, \&c. A curious example of the use of such foliated ornaments appears on the round seal of Westminster Abbey.

${ }_{2}^{2}$ Archæologia, vol. v., p. 353. 
opinion, constituted his investiture, by its formal receipt from the diocesan. ${ }^{3}$ To the small number, of which Mr. Dansey gives representations, the seal of Pawlett forms an interesting addition.

3. Seal of the Deanery of Hengham. The device is singular, a saltire, or St. Andrew's cross, raguly.-_-Sigillu. deconatus : ye. hengham. In the

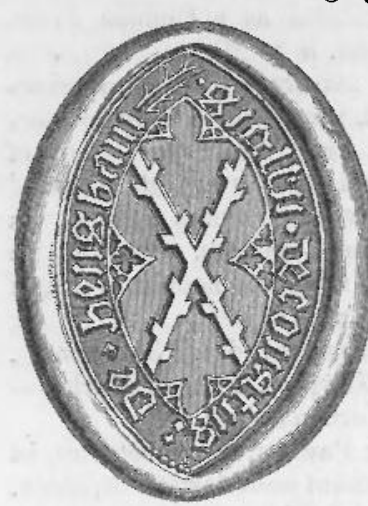

Silver Seal. Deanery of Hengham. Taxation of Pope Nicholas IV. is found an ecclesiastical division in the Diocese of London, entitled "Decanatus de Hengham," or Hedingham, comprising Toppesfield, Sible Hedingham, (written Hengham,) and many other parishes in Essex. ${ }^{+}$This is now in the Archdeaconry of Colchester, in the Diocese of Rochester. The rural deanery, to which this seal appertained, was doubtless the "Decanatus de Hengham," in the Diocese of Norwich, which receives its name from the town of Hingham, and comprised forty-three parishes. ${ }^{5}$ The church was dedicated to St. Andrew, and this accounts for the device upon the seal. Blomefield gives a list of deans during the fourteenth and fifteenth centuries. This interesting relic is formed of silver, and it is now preserved in the choice cabinet of Norfolk relics, in the possession of Mr. Robert Fitch, of Norwich.

4. Seal of Henry, Abbot of Revesby, Lincolnshire. This is of pointed oval form, measuring $2 \frac{1}{2}$ inches by $1 \frac{1}{2} \mathrm{inch}$. The device is the Virgin and infant Saviour ; she is seated under a richly crocketed canopy ; a sceptre in her hand, a crown of stars, or of flowers, upon her head. The inscrip-

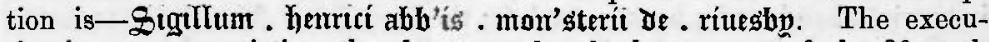
tion is not very artistic ; the date may be the latter part of the fifteenth century. The Cluniac Abbey of Revesby was dedicated to St. Mary and St. Lawrence. No abbot named Henry is found in the list given in the new edition of the "Monasticon," (vol. v, p. 453). There is, however, a total hiatus during the fifteenth century.

The matrix was found on the site of Ewenny Priory, Glamorganshire, a cell to Gloucester, and it is in the possession of Colonel Turberville. An impression was produced, with the following seal, by Mr. Franks.

5. Common seal of the Fraternity of the Holy Trinity, Cardiff. A circular seal, of rude execution-diameter, $1 \frac{1}{6}$ inch. The device is the conventional representation of the Trinity, the Supreme Being seated, and holding a crucifix between his knees. The holy dove descends upon the Saviour's head. $\Im$. f'rís trimtatis ye kardif in galia. It was found at Llantwit Major, Glamorganshire, and is in the possession of John Nicholl Carne, Esq., LL.D.-Date, fifteenth century.

6. Seal of pointed-oval form, probably the personal seal of an ecclesiastic ; the device is the Virgin seated, and holding the infant Jesus. Legend-*Ave MARIa gRaCIa PLEN. Date, fourteenth century. The matrix was found amongst the ruins of Reading Abbey, in digging the foundations for the new county prison. It was presented to the Rev. J. Kingrose by the clerk of the works, but was subsequently claimed by the sheriff, and given up.

${ }^{3}$ Horæ Decanicæ Rurales, vol. i., p. 387.

4 Taxatio Eccles., pp. 16, 18, 20.
5 Ibid., pp. 85, 107 ; Blomefield's Hist. of Norfolk, vol. ii., p. 422. 
Impression sent by Miss Julia R. Bockett, of Reading.

7. Personal Seal, with an heraldic device. It is circular; diameter, nearly 1 inch. The centre is occupied by an escutcheon, a fess, with a demi-lion in chiefis in the possession of the Rev. James Lee Warner, and was found near Walsingham, in 1847. The arms may be those of Esme, or Esmey.

8. Seal of John Bysshe. Circular seal ; diameter, $11^{1}$ inch ; in the centre an escutcheon of the arms of Bysshe,-a chevron between three cinqfoils (or roses); a single-headed eagle displayed seems to support the shield, and on each side of it is an initial, J. and B.- - igillum tohannts busshe armig'. Matrix formerly in the possession of the late Mr. Douce. Date, early in the fifteenth century. Edward Bysshe, in his Notes on Upton, p: 53, remarks that the elder branch of the De la Bisse family, descended from Baldwin de Clare, bore the arms of Clare, 3 chevronels, differenced by a label of five points. But, about $t$. Rich. II, on account of an alliance with the Staffords, the arms, borne by himself, were adopted, a chevron between 3 roses, as seen on the seal of Sir Thomas Bysshe, 5 Rich. II. It appears from Manning and Bray's Hist. of Surrey, vol. ii., p. 286, that there was a John de Byshe living t. Edward III., also another John, t. Hen. VI., whose son bore the same name.

9. Seal of Hugh of Bourdeaux. Fourteenth century. A small circular seal ; diameter, $\frac{3}{4}$ inch. The matrix was found at Winchester, in 1849 , in the following singular position. The bark of an old tree having accidentally been struck off by a blow, the seal was discovered underneath the bark. The device is the Holy Lamb. The cross surmounting the bannerstaff forms likewise the initial of the legend- $-s$ ' Hv GoNis DE BVRdevs. Communicated by Mr. Hawkins.

10. Personal Seal, with device and motto, of the time of Henry VI. This interesting Signet, of which by the kindness of Dr. Kidd, Regius Professor of Medicine at Oxford, a representation is given, is one

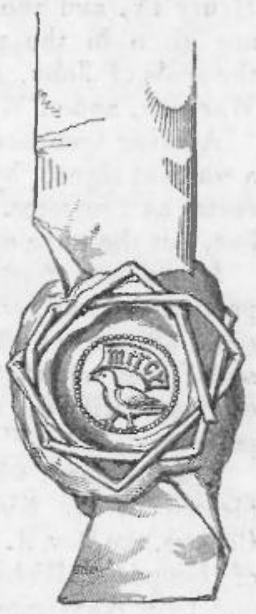
of three small seals appended to a letter of attorney, dated 1433, amongst the curious documents preserved in the charter-chest of Ewelme Hospital, of which the Regius Professor is ex officio the Master. The seal is probably the impress of a ring; it is of red wax. The device is apparently a dove, holding in her mouth a scroll inscribed-mercy. The rush twisted around the impression to preserve it from being defaced, and seemingly in the form of two interlaced squares, is a peculiarity of interest. ${ }^{6}$ The three impressions are made upon separate slips, cut horizontally at the lower margin of the little deed, of which they form part, in lieu of the more customary dependent labels of a separate slip, passed through a slit in the parchment. The uppermost seal of the three bears as a device the stock of a tree, with two boughs; the second, a pelican in piety. The lowest slip bears the little impress here shown. It may be the seal of Andrew Sperlynge, the third named in the instrument. The bird may be a sparrow, with an allusion to his name.

${ }^{6}$ Compare the fashion of squares interlaced, as on Mr. Hamper's curious seal, Gent. Mag., No. xev., Pt. ii., pl. 11. 
Sir Francis Palgrave observes, in regard to the mass of ancient correspondence in the Treasury of the Exchequer, that in the fourteenth century the wax was left uncovered : in the fifteenth it became the practice to cover it by a wrapper of paper; this protected the seal, but necessarily injured the sharpness of the impression. When the seal was not thus covered, other devices were adopted to preserve the fragile wax. A rush ring surrounding the impression was not unfrequently used. Sometimes neat bands of plaited paper were employed for this purpose; leaves of trees - the beech, the bay, and the oak-were also placed over the seals to keep them from injury. ${ }^{7}$ The example given by Sir Francis, in the plates of Illustrations, is of rather late date. It occurs on a letter (written upon paper) from James IV. of Scotland to Henry VII., dated July 12, 1502. The seal is encircled by a twist of rush, like the torse of a crest. ${ }^{8}$

This peculiar usage commenced possibly rather earlier than has been stated by the eminent antiquary above cited. Specimens are not wanting from about 1380 to the reign of Henry VIII. It prevailed chiefly during the reign of Henry IV. and the two succeeding sovereigns. Several curious examples are given in the plates accompanying the Paston Letters; for instance, the seals of John, Lord Lovell, t. Henry VI., of Richard Neville, Earl of Warwick, and of William Yelverton, about $1450 .^{9}$

Another specimen is pointed out by Sir Frederic Madden. It occurs on a warrant signed by Edward V., and countersigned by the Duke of Gloucester as Protector. It is dated 1483. The impression is unfortunately lost, but the torse of rush remains which had encircled it. ${ }^{1}$

It has been observed, that seals protected by this "fender" of rush, to prevent the wax being flattened by pressure, are of more frequent occurrence affixed to a plain surface, such as a sheet of paper, than as appended seals, such as that here represented. It is probable that the practice originated with the use of seals thus applied, and their liability to injury by pressure.

The document which has supplied this interesting example was communicated by Dr. Kidd, through the kindness of the President of Trinity College, the Rev. J. Wilson. It is a letter of attorney from John Hampdene, of Hampdene, Richard Restwolde, and Andrew Sperlynge, to John Uptone and John Whytynge, to receive seisin of the manors of Nortone (Somerset), Connoke (Wilts), and Ramrugge (Hants), according to the form and effect of a certain writing from William de la Pole, Earl of Suffolk, to them, John Hampdene, Richard and Andrew. Dated Aug. 6th, 11 Hen. VI. (1433).)

11. The following seals were communicated by Mr. Majendie.-A brass matrix, of the fourteenth century, recently found at Great Yeldham, Essex, the device a hare blowing a hunting-horn, and mounted on a hound:* SOHOV ROBIN. Date about 1320.

12. Seal found at East Bourne ; it bears an escutcheon, semy of cross crosslets, fitchy, a lion rampant, the arms of the Sussex family named Levett. Inscription, * SIG'. IOHANNIS- LIVET. The owner of this seal, as Mr. Walford has suggested, was probably the John Livet, certified Lord of the township of Firle, Sussex, in 1316. (Parl. Writs, vol. ii., pt. ii., p. 335).

A. W.

i Kalendars of Exch., Introd., vol. i., p. exxxvii.

8 Paston Letters, orig. edit., vol. ii., pl. xiv.

9 Archæologia, vol. xxx., p. 545, pl. xxiii.

1 Ibid., pl. iv. 